\title{
Alternative approach to management of Rhizopus rot of peach (Prunus persica L.) using the essential oil of Thymus vulgaris (L.)
}

\author{
Taheri P*, Ndam LM, Fujii Y
}

Department of International Environmental and Agricultural Science, United Graduate School of Agricultural Science, Faculty of Agriculture, Tokyo University of Agriculture and Technology: 3-5-8 Saiwai-cho, Fuchu-shi, Tokyo 1838509, Japan.

Taheri P, Ndam LM, Fujii Y 2018 - Alternative approach to management of Rhizopus rot of peach (Prunus persica L.) using the essential oil of Thymus vulgaris (L.). Mycosphere 9(3), 510-517, Doi 10.5943/mycosphere/9/3/5

\begin{abstract}
A great proportion of peach fruit production is lost yearly because of Rhizopus soft rot caused by Rhizopus stolonifer. In developed countries, consumer preference to organic produce is growing and many produce-importing countries are enforcing strict regulations regarding minimum fungicide levels in fruits. Postharvest fruit-pathogenic fungi are developing resistance to synthetic fungicides and the indiscriminate disposals of these fungicides is worrying. Hence, the objective of this study was to evaluate the efficacy of the essential oil of Thymus vulgaris for the control of $R$. stolonifer growth on Peach fruits under in vitro and in vivo conditions. Treatments consisted of five concentrations of the essential oil of $T$. vulgaris ranging from $0-800 \mu \mathrm{L} / \mathrm{L}$. The essential oil of $T$. Vulgaris at all concentrations inhibited $R$. stolonifer growth in a dose-dependent manner ranging from $94.280 \%$ at $800 \mu \mathrm{L} / \mathrm{L}$ to $82.230 \%$ at $200 \mu \mathrm{L} / \mathrm{L}$. Treated-fruits reserved their marketable qualities with lower decay severity scores, higher total soluble solids, anthocyanin and carbohydrate contents compared to control. This study has affirmed that the essential oil of $T$. vulgaris is a viable alternative to synthetic fungicides and should therefore be prioritised in the control of postharvest loses of fruits and vegetables.
\end{abstract}

Key words - Bioactivity - Rhizopus Rot - Postharvest Disease - Essential oils - Stone fruit

\section{Introduction}

Peach (Prunus persica L.) fruit with, pink, yellow and red colour skin and native to Asia is considered as the "Queen" of the fruits and second most popular fruit after apple. Statistics from 47 countries reported 21.1 Million tons of commercially produced Peach in 2012 (FAO 2014, Ingrao et al. 2015). The fruit is known for its palatability, abundant nutrients and health benefits and constitutes a significant volume of trade and revenue to the Iranian economy. Iran is ranked $7^{\text {th }}$ in the world for producing over 1.15 million tons of Peach/year in 52,400 ha of land, indicating a $6.8 \%$ rise year-on-year (FAO 2008, FIED 2018). Peach with an acceptable level of quality are sold from 25,000 Rials (US\$0.6) to 60,000 Rials (US\$1.4) per kilogram in Iran (FIED 2018). The production figures and fruit quality are far from matching demand and marketable quality as a result of susceptibility to postharvest diseases and environmental factors which account for significant losses in storage 
Peach fruit is vulnerable to a plethora of postharvest phytopathogenic fungi during storage, especially the cosmopolitan Rhizopus stolonifer that causes Rhizopus rot. Anecdotal evidence opined that $R$. stolonifer is unpredictable and accounts for heavy losses which sometimes destroy entire shipments in severe cases (ITA 2016). Grey hyphae which emerge from infected portions produce aerial sporangiosphores with black spherical sporangia which cause a terminal break down of tissues, leakage and disintegration into watery rot (El Arbi et al. 2014). This leads to decay and reduction of market value of the fruit because of deformation, rot and nutrient depletion. To avoid these devastations, synthetic fungicides such as Dicloran are used in postharvest treatment (Clark \& Hoy 1994). Synthetic pesticides have environmental and health implications, necessitating bioprospecting and use of alternative eco-friendly approach such as botanical fungicides to curb post-harvest loses of Peach fruits caused by $R$. stolonifer.

Essential oils from plants are complex volatile compounds usually characterised by strong fragrance (Pina-Vaz 2004, Bakkali et al. 2008) and have been reported for in vitro antimicrobial, anticancer, analgesic, antioxidant, anti-inflammatory, immunomodulatory, and antithrombotic activities (Ultee et al. 1999, Inouye et al. 2001, 2006, Matan et al. 2006, Tomlinson \& Palombo 2005). Essential oil-producing plants harbour a rich treasury of bioactive principles that defend plants against herbivores (Burt 2004). Takayuki et al. (2007) investigated the in vitro antifungal activity of 52 dried samples of spice and herbs against Fusarium oxysporum. In another study, Chebli et al. (2003) screened the essential oils of Origanum compactum and Thymus glandulosus against Botrytis cinerea. Soylu et al. (2010) reported that essential oils obtained from aerial parts of an aromatic plant, lavender (Lavandula stoechas L. var. stoechas) completely inhibited the growth of Botrytis cinerea. Increasing reports of antimicrobial activity exhibited by essential oils extracted from plants have renewed interest in the use of natural products in the control of postharvest diseases of fruits and vegetables. In developed countries, consumer preference to organic produce is growing and many produce-importing countries are enforcing strict regulations regarding minimum fungicide levels in fruits. In addition, postharvest fruit-pathogenic fungi are developing resistance to synthetic fungicides and there have been rising environmental concerns regarding the indiscriminate disposals of fungicides. Hence, the objective of this study was to evaluate the efficacy of the essential oil of the Iranian medicinal plant, Thyme (Thymus vulgaris) in the control of $R$. stolonifer growth on Peach fruits under in vitro and in vivo conditions.

\section{Materials \& Methods}

\section{Plant materials and Extraction of essential oil}

Powdered leaves of $T$. vulgaris $(100 \mathrm{~g})$ was subjected to hydro distillation for three hours in a Clevenger type apparatus and the oil obtained was anhydrously dried over $\mathrm{Na}_{2} \mathrm{SO} 4$ and stored at $4^{\circ} \mathrm{C}$ until use. $R$. stolonifer isolated from infected Peach fruits obtained from an agricultural farm in Iran was cultured on potato dextrose agar (PDA) in a petridish for 7 days and later sealed with paraffin wax, then stored at $4^{\circ} \mathrm{C}$ till further use.

\section{In vitro antifungal evaluation of $T$. vulgaris essential oil on $R$. stolonifer using Agar Dilution Method}

Appropriate volumes of the essential oil of T. vulgaris were diluted in $10 \mathrm{~mL}$ of Tween 80 $(5 \% \mathrm{v} / \mathrm{v})$ to obtain final working concentrations of $0,200,400,600$ and $800 \mu \mathrm{L} / \mathrm{mL} .0 .5 \mathrm{~mm}$ mycelium disc of $R$. stolonifer of 7days culture was placed on PDA plates having $20 \mathrm{ml}$ of agar at $45^{\circ} \mathrm{C}$ and impregnated with essential oil. Plates were sealed with paraffin and incubated for 7 days at $24^{\circ} \mathrm{C}$. Four replications were used for each treatment. The inhibitory percentage was calculated as per the formula:

$$
\text { IP }=\underline{\operatorname{dedt} X 100}
$$


$\mathrm{IP}=$ Inhibitory percent, $\mathrm{dc}=$ mycelium growth diameter in control and $\mathrm{dt}=$ mycelium growth diameter in essential oil treated Petri dish.

\section{Antifungal evaluation of the essential oil of $T$. vulgaris on $R$. stolonifer using fumigation method}

A paper disc (6 $\mathrm{mm}$ in diameter) injected with varied concentrations of essential oil was placed on the lid of a plate and was used to cover PDA plates inoculated at the centre with $1 \times 10^{5}$ $\mathrm{cfu} / \mathrm{L}$ of $R$. stolonifer. Petri dishes were sealed with paraffin and the plates were incubated at $24^{\circ} \mathrm{C}$ for seven days. The colony growth diameter and percentage inhibition was determined as described above. The experiment was factorially arranged in a completely randomised design with four replications per treatment.

\section{Effect of the essential oil of $\boldsymbol{T}$. vulgaris on some postharvest quality factors of Peach Fruits}

Mycelial suspension of $R$. stolonifer $\left(1 \times 10^{5} \mathrm{cfu} / \mathrm{L}\right)$ was fixed on five healthy Peach fruits which were sterilized with $2.5 \% \mathrm{NaClO}$ and later placed in different concentrations $(0,200,400$, 600 and $800 \mu \mathrm{L} / \mathrm{L}$ ) of $T$. vulgaris for 30 seconds. The set up was replicated three times. Treated fruits were packaged and stored at $4{ }^{\circ} \mathrm{C}$ and later assessed for total soluble solids, titrable acidity, weight loss, rottenness, anthocyanin and carbohydrate contents after 15 days, according to standard protocol (Mohammadi \& Aminifard 2012).

\section{Incidence of fruit decay under cold storage conditions}

Infection of fruits by $R$. stolonifer was rated using a scale of 0 to 8 , where $0=$ no infection; 1 $=$ traces of infection lower than 10\%, $2=$ infection between 10-20\%, $3=$ infection between 21 $30 \%, 4=$ infection between $31-40 \%, 5=$ infection between $41-50 \%, 6=$ infection between 51-60\%, $7=$ infection between $61-80 \%$ and $8=$ infection $>80 \%$ (Asghari Marjanlo et al. 2009). Fruits treated with essential oil, untreated fruits and the negative control (fruits treated with sterile distilled water) were transferred into packages, sealed in order to prevent oil loss and then kept in cold storage $\left(4^{\circ} \mathrm{C}\right)$.

\section{Titrable acidity (TA), Total soluble solids (TSS) and pH}

The $\mathrm{pH}$ of Peach fruits was determined using an Electrochemist $\mathrm{pH}$ meter (200 Series/Model 215 ) at $20^{\circ} \mathrm{C}$. Titratable acidity (TA) was determined by titration with $0.1 \mathrm{~N} \mathrm{NaOH}$ until $\mathrm{pH} 8.1$ was reached and reported in grams per $100 \mathrm{~g}$ of malic acid fresh weight using malic acid as a control (Horwitz 1975). Total soluble solids (TSS) was determined at $20^{\circ} \mathrm{C}$ with a digital Refractometer (model RFM340, UK) and reported as Brix (Mohammadi \& Aminifard 2012).

\section{Weight loss percentage}

Weight loss of treated and untreated fruits was determined by subtracting the weight of the fruits after 15 days of storage from the initial weight (weight before storage). Fruits were weighed with a Jewelry Balance (Model 34088).

\section{Anthocyanin}

The $\mathrm{pH}$ differential method as described by Rapisarda et al. (2000) was employed to determine the total anthocyanin content. Two samples of $1 \mathrm{~mL}$ each of Peach essential oil were separately diluted up to $10 \mathrm{ml}$ with $\mathrm{pH} 1.0$ solution $(125 \mathrm{~mL}$ of $0.2 \mathrm{M} \mathrm{KCl}$ and $375 \mathrm{~mL}$ of $0.2 \mathrm{M}$ $\mathrm{HCl})$ and a $\mathrm{pH} 4.5$ buffered solutions $(400 \mathrm{~mL}$ of $1 \mathrm{M} \mathrm{CH} 3 \mathrm{CO} 2 \mathrm{Na}, 240 \mathrm{ml}$ of $1 \mathrm{M} \mathrm{HCl}$, and $360 \mathrm{ml}$ of $\mathrm{H} 2 \mathrm{O}$ ). The absorbance of the solution was determined at $510 \mathrm{~nm}$ and the concentration of anthocyanins was calculated by the equation:

$$
\mathrm{Cmg} / 100 \mathrm{~g}=[(\mathrm{AbspH} 1.0-\mathrm{AbspH} 4.5) \times 484.82 \times 1000 / 24825] \times \mathrm{DF} .
$$


Where the term in parentheses is the difference of absorbance at $510 \mathrm{~nm}$ between $\mathrm{pH} 1.0$ and $\mathrm{pH}$ 4.5 solution, 484.82 is the molecular mass of cyanidin-3-glucoside chloride, 24825 is it molar absorptivity $(\varepsilon) \mathrm{nm}$ in the $\mathrm{pH} 1.0$ solution, and DF is the dilution factor.

\section{Carbohydrate}

The Carbohydrate composition of peach fruit was determined by the method of Yemm \& Willis (1954) using anthrone reagent. Ethanol was used to extract sugar at $45^{\circ} \mathrm{C}$, followed by centrifugation at $5000 \mathrm{~g}$ for 10 Minutes. The resultant mixture, an integration of $0.5 \mathrm{~mL}$ of anthrone reagent was boiled at $100^{\circ} \mathrm{C}$ for 30 minutes. The Absorbance was measured at $620 \mathrm{~nm}$ and the carbohydrate content expressed in $\mathrm{mg} / \mathrm{g}$ dry weight.

\section{Statistical analysis}

The data were expressed as means using statistical analysis software (SAS 9.1) and statistically significant differences among treatment means were determined by one-way Analysis of Variance (ANOVA) at 5\% significance level. Duncan's multiple range test (DMRT) was used to segregate means.

\section{Results}

Effects of the essential oil T. vulgaris on $R$. stolonifer growth in vitro.

The antifungal activity of the essential oil of T. vulgaris was determined by agar diffusion and fumigation assays and expressed as inhibitory percentage and inhibition zone (as measured by diameter of radial growth). The essential oil of $T$. Vulgaris at all concentrations inhibited $R$. stolonifer growth in a dose-dependent manner (Table 1) ranging from $94.280 \%$ at $800 \mu \mathrm{L} / \mathrm{L}$ to $82.230 \%$ at $200 \mu \mathrm{L} / \mathrm{L}$. The highest radial growth diameters $(52.040 \mathrm{~mm}$ and $45.420 \mathrm{~mm})$ was observed at $0 \mu \mathrm{L} / \mathrm{L}$ (control) in the diffusion and fumigation assays respectively. The lowest radial growth diameters $(4.620 \mathrm{~mm}$ and $3.900 \mathrm{~mm})$ with the essential oil of T. vulgaris was recorded at $800 \mu \mathrm{L} / \mathrm{L}$ for dilusion method and fumigation method respectively.

Table 1 Effect of the essential oil of Thymus vulgaris on the growth of $R$. stolonifer.

\begin{tabular}{ccccc}
\hline \multirow{2}{*}{$\begin{array}{c}\text { Concentration } \\
(\boldsymbol{\mu L} / \mathbf{L})\end{array}$} & \multicolumn{2}{c}{ Dilution method } & \multicolumn{2}{c}{ Fumigation method } \\
\cline { 2 - 5 } & $\begin{array}{c}\text { Radial growth } \\
(\mathrm{mm})\end{array}$ & $\begin{array}{c}\text { Inhibitory effect } \\
(\%)\end{array}$ & $\begin{array}{c}\text { Radial growth } \\
(\mathrm{mm})\end{array}$ & Inhibitory effect $(\%)$ \\
\hline $\mathbf{0}$ & $52.040 \mathrm{a}$ & $0.000 \mathrm{e}$ & $45.420 \mathrm{a}$ & $0.000 \mathrm{c}$ \\
$\mathbf{2 0 0}$ & $14.480 \mathrm{~b}$ & $82.230 \mathrm{~d}$ & $9.900 \mathrm{~b}$ & $74.440 \mathrm{~b}$ \\
$\mathbf{4 0 0}$ & $10.870 \mathrm{c}$ & $85.710 \mathrm{c}$ & $7.060 \mathrm{c}$ & $77.350 \mathrm{~b}$ \\
$\mathbf{6 0 0}$ & $7.620 \mathrm{~d}$ & $88.900 \mathrm{~b}$ & $4.120 \mathrm{~d}$ & $78.460 \mathrm{~b}$ \\
$\mathbf{8 0 0}$ & $4.620 \mathrm{e}$ & $94.280 \mathrm{a}$ & $3.900 \mathrm{~d}$ & $84.800 \mathrm{a}$ \\
\hline
\end{tabular}

Means with different letter in a column are statistically significant at $5 \%$ level probability.

\section{Effect of the essential oil of $T$. vulgaris on some postharvest parameters of Peach Fruits}

Treated-fruits reserved their marketable qualities with lower decay severity scores and no infection registered at $800 \mu \mathrm{L} / \mathrm{mL}$ as opposed to the non-treated fruits that showed sustained increased deterioration with a score of 8.23 at $0 \mu \mathrm{L} / \mathrm{L}$ (Fig. 1). 


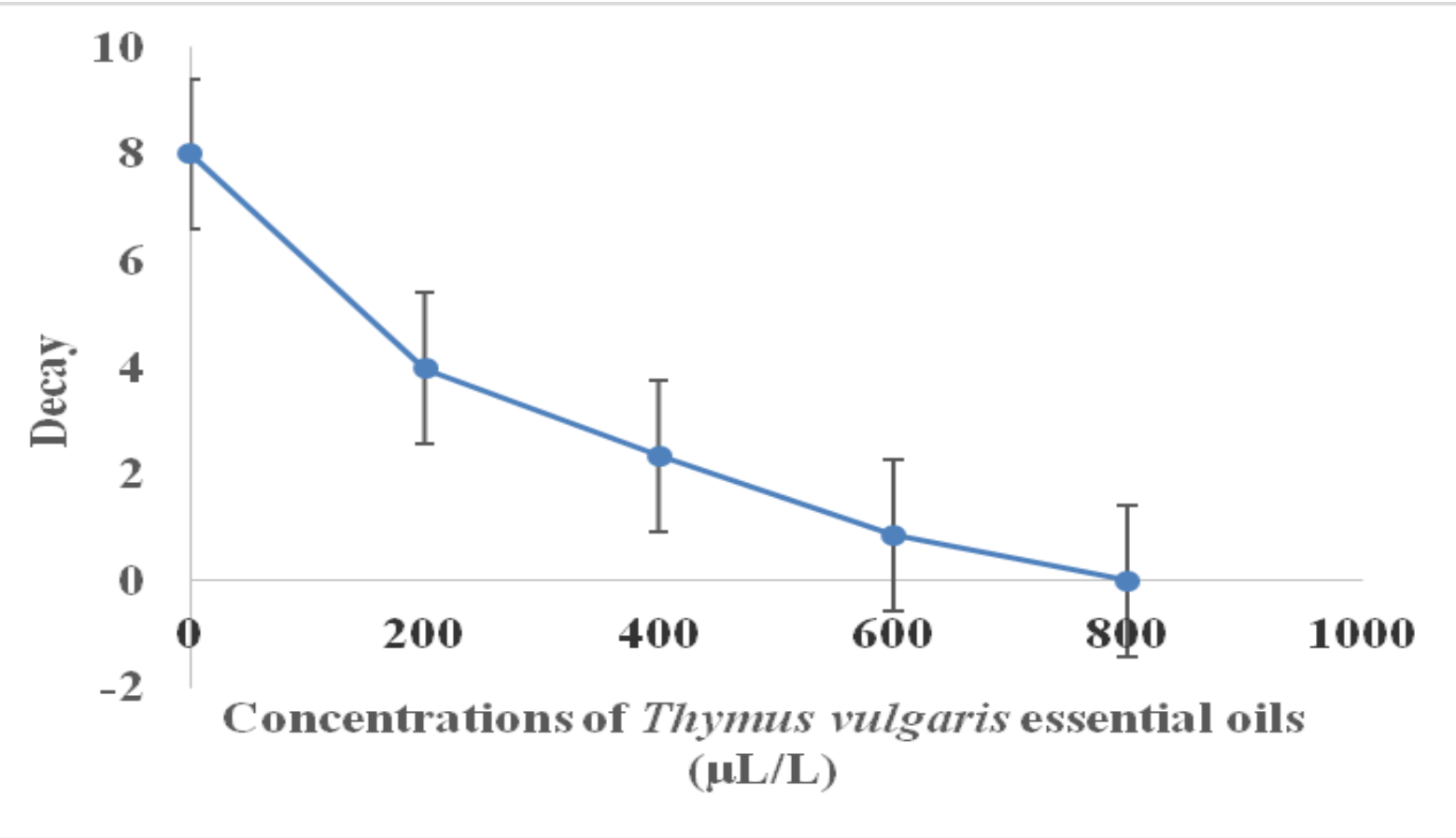

Figure 1 - Effect of essential oil of Thymus vulgaris on the decay severity of Peach fruits

Peach fruits that were treated with $T$. vulgaris essential oil had more total soluble solids, TA, anthocyanin and carbohydrate content in comparison to control (Table 2). There was significant difference in $\mathrm{pH}$ value, among treatments and control. The anthocyanin content of the treated peach fruits were significantly higher than that of the control. The greatest anthocyanin content was observed in fruits treated with $400 \mu \mathrm{L} / \mathrm{L}$ essential oils $(21.45 \mathrm{mg} / 100 \mathrm{~g})$, while the control had the least value. Fruits treated with essential oil at $400 \mu \mathrm{L} / \mathrm{L}$ had the highest TSS content $\left(15.35^{\circ} \mathrm{Brix}\right)$ while for TA, essential oil at $400 \mu \mathrm{L} / \mathrm{L}$ was the best treatment $(0.99 \mathrm{~g} / 100 \mathrm{~g})$. Fruits treated with essential oil at $400 \mu \mathrm{L} / \mathrm{L}$ had the lowest $\mathrm{pH}$ value (2.98), while control fruits had the highest $\mathrm{pH}$ (3.41). Similarly, treated fruits had the highest carbohydrate content at $400 \mu \mathrm{L} / \mathrm{L}(191.30 \mathrm{mg} / 100 \mathrm{~g})$ while control fruits had the lowest carbohydrate content $(130.30 \mathrm{mg} / 100 \mathrm{~g})$.

Table 2 Effect of the essential oil of T. vulgaris on postharvest quality factors of Prunus persica (Peach)

\begin{tabular}{cccccc}
\hline $\begin{array}{c}\text { Concentration } \\
(\mu \mathrm{L} / \mathrm{L})\end{array}$ & $\mathrm{TSS}\left({ }^{\circ}\right.$ Brix $)$ & $\mathrm{TA}(\mathrm{g} / 100 \mathrm{~g})$ & $\mathrm{pH}$ & $\begin{array}{c}\text { Anthocyanin } \\
(\mathrm{mg} / 100 \mathrm{~g})\end{array}$ & $\begin{array}{c}\text { Carbohydrate } \\
(\mathrm{mg} / 100 \mathrm{~g})\end{array}$ \\
\hline 0 & & & & & \\
\hline 200 & $12.70^{\mathrm{a}}$ & $0.72^{\mathrm{a}}$ & $3.41^{\mathrm{a}}$ & $13.65^{\mathrm{a}}$ & $130.30^{\mathrm{a}}$ \\
400 & $15.19^{\mathrm{bc}}$ & $0.89^{\mathrm{bc}}$ & $3.00^{\mathrm{bc}}$ & $19.00^{\mathrm{bc}}$ & $167.30^{\mathrm{bc}}$ \\
600 & $15.33^{\mathrm{bc}}$ & $0.99^{\mathrm{cd}}$ & $2.98^{\mathrm{bc}}$ & $21.45^{\mathrm{de}}$ & $191.31^{\mathrm{de}}$ \\
800 & $13.85^{\mathrm{de}}$ & $0.89^{\mathrm{df}}$ & $3.10^{\mathrm{cd}}$ & $19.43^{\mathrm{cf}}$ & $178.28^{\mathrm{fg}}$ \\
\hline
\end{tabular}

Same letter in each column, indicates no significant difference between treatments at $5 \%$ levels

Percentage weight of treated fruits was significantly lower compared to control $(\mathrm{P}<0.01)$. Treated fruits with $400 \mu \mathrm{L} / \mathrm{L}$ had the lowest $\%$ weight loss $(7.11 \%$ ) followed by $600 \mu \mathrm{L} / \mathrm{L}$ (Fig. 2 ). 


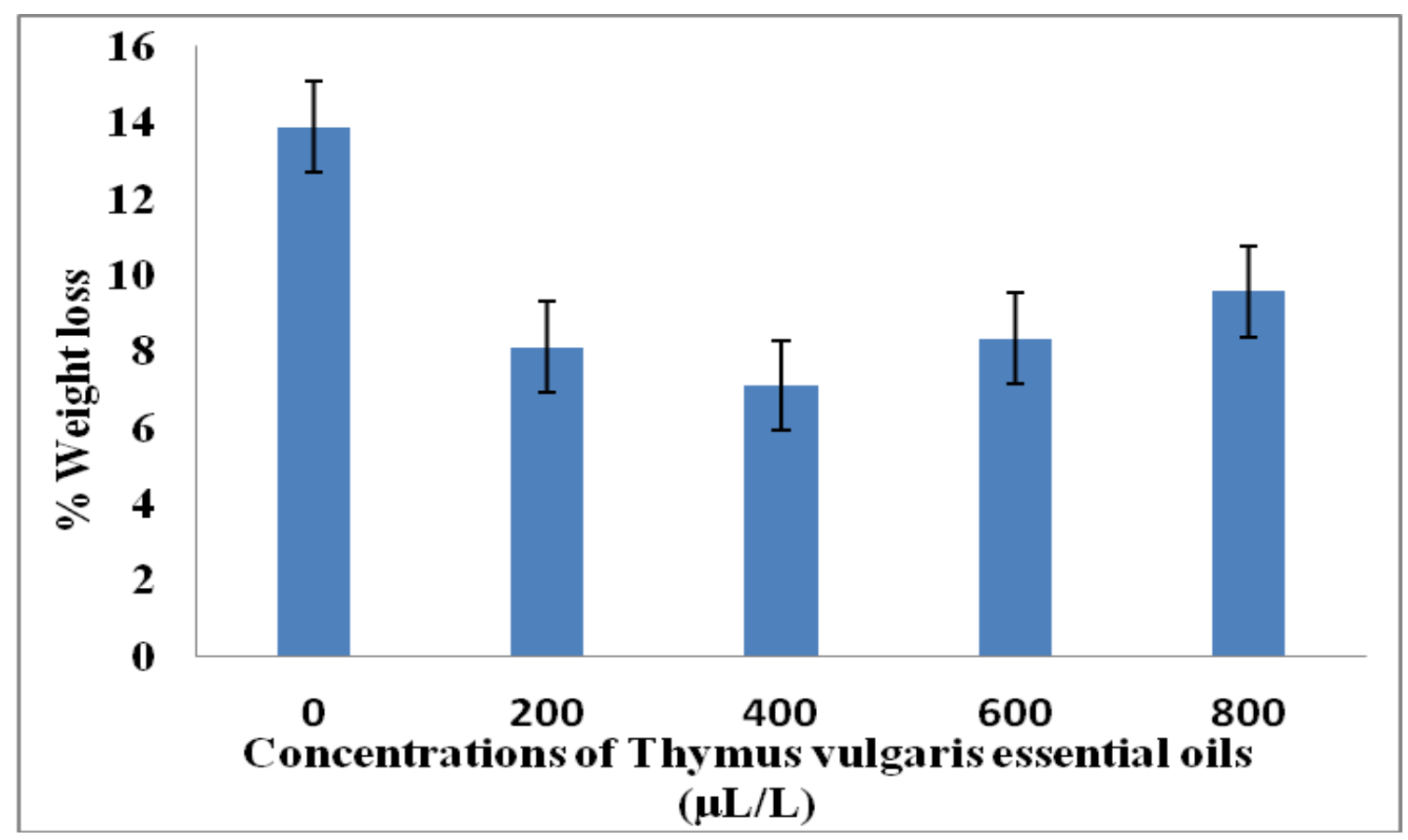

Figure 2 - Effect of Essential oil of Thymus vulgaris on weight loss of Prunus persica (Peach)

\section{Discussion}

Results from the in vitro assays showed that the essential oil of $T$ vulgaris possessed antifungal property at higher concentrations especially at 800 and $400 \mu \mathrm{L} / \mathrm{L}$. The inhibitory effect of essential oils from Thymus species on fungal growth has been reported by many authors. Wilson et al. (1999) reported that the essential oil extracted from red thyme (Thymus zygis L.) had a great inhibitory effect on Botrytis cinerea spore germination compared with other tested essential oils. Essential oils of Thymus glandulosus was fungicidal to Botrytis cinerea mycelia, spore germination and elongation of germ tube were greatly inhibited (Chebli et al. 2003). Botrytis cinerea and Fusarium sp. were susceptible to thyme essential oils at relatively low doses (Dimitra et al. 2003). The antifungal property of Thymus species may be attributed to the presence of bioactive compounds in their essential oils. The compounds thymol and carvacrol isolated from T. vulagaris essential oil account for the antifungal activity of the oil. Camele et al. (2012) reported that thymol inhibited the growth of Rhizopus stolonifer at a concentration of $250 \mathrm{ppm}$ while carvacrol and citral completely inhibited the mycelia Botrytis cinerea at a concentration of $250 \mathrm{ppm}$. These compounds may act in synergism or independently. The mode of action of these compounds is grounded on their ability to interact with cell wall glucans, acetylglucosamine polymers and polysaccharides, thereby altering the permeability of fungal cell walls. This results to a deformation in structure, function and loss of macromolecules from fungal cells (Rattanapitigorn et al. 2006).

The results of this study also showed that the essential oil positively affected the storage life of Peach fruits by reducing decay content. Reduction of fruit decay during postharvest treatments with essential oil extracted from various medicinal plants has been reported by various authors (Williamson et al. 2007, Mohammadi \& Aminifard 2012). This study also showed that the essential oil of T. vulgaris effectively maintained Peach fruit quality. Treated fruits had more TA, carbohydrate content, total soluble solids and anthocyanin compared to control. Carvacrol and other naturally occurring essential oils such as cinnamic acid, linalool, $p$-cymene, anethole and perillaldehyde were tested for their ability to increase antioxidant levels and reduce decay in blueberries. All the essential oils decreased fruit decay to some degree compared to controls (Wang et al. 2008). In this study, application of the essential oil of T. vulgaris significantly decreased weight loss in treated fruits. Previous studies using natural antifungals such as thymol, menthol vapour and eugenol reduced weight loss in grapes and cherries (Serrano et al. 2005). Postharvest pathogenic fungi accelerate the rate of ethylene production in stored fruits and this may be partially 
responsible for postharvest damages in fruits since a linear correlation between ethylene and fruit damage has been observed (Cristescu et al. 2002). Hence, the respiration rate of the treated Peach fruits was clearly affected since the fungus that could have been expediting ethylene production was inhibited by the essential oil of T. vulgaris.

Postharvest decay caused by Rhizopus stolonifer clearly reduces the shelf-life of peach fruits. However, results of this study have shown that the essential oil of T. vulgaris is a viable alternative to synthetic fungicides and should therefore be prioritised in the control of postharvest loses of fruits and vegetables .

\section{Conclusion}

This study was undertaken to evaluate the efficacy of essential of $T$. vulgaris against $R$. stolonifer growth on Peach fruits. Given the inhibition of $R$. stolonifer growth, lower decay severity scores, higher total soluble solids, anthocyanin and carbohydrate contents in treated fruits compared to control, we conclude that $T$. vulgaris essential oil could be used as possible bio fungicides in the control of $R$. stolonifer. However, toxicity studies are required to determine the safety of fruits treated with the essential oil of T. vulgaris.

\section{Acknowledgement}

We thank farmers of Mashhad, Iran for facilitating Peach disease fruit collection.

\section{References}

Asghari Marjanlo A, Mostofi Y, Shoeibi Sh, Fattahi M. 2009 - Effect of Cumin Essential Oil on Postharvest Decay and Some Quality Factors of Strawberry. Journal of Medicinal Plants 8(31), 25-43.

Bakkali F, Averbeck S, Averbeck D, Idaomar M. 2008 - Biological effects of essential oils - A review Food and Chemistry Toxicology 46, 446-475.

Burt S. 2004 - Essential oils: their antibacterial properties and potential applications in foods-a review. International Journal of Food Microbiology 94, 223-253.

Camele I, Altieri L, De Martino L, De Feo V et al. 2012 - In Vitro Control of Post-Harvest Fruit Rot Fungi by Some Plant Essential Oil Components. International Journal of Molecular Science, 13, 2290-2300

Chebli B, Achouri LM, Idrissi H, Mohamed H. 2003 - Chemical composition and antifungal activity of essential oils of seven Moroccan Labiatae against Botrytis cinerea Pers: Fr. Journal of Ethnopharmacology 89, 165-169.

Clark CA, Hoy MW. 1994 - Identification of resistance in sweet potato to Rhizopus soft rots using two inoculation methods. Plant Disease 78, 1078-1082.

Cristescu SM, De Martinis D, Hekkert SL, Parker DH, Harren FJM. 2002 - Ethylene production by Botrytis cinerea in vitro and in tomatoes. Applied Environmental Microbiology 68, 53425350

Dimitra J, Daferera Basil N, Ziogas M, Polissiou G. 2003 - The effectiveness of plant essential oils on the growth of Botrytis cinerea, Fusarium sp. and Clavibacter michiganensis subsp. Michiganensis. Journal of Crop Protection 22, 39-44.

El Arbi B, EL Idrissi SBS, Kadmiri Issam M, Lahoucine H, Abderraouf H. 2014 - Screening of Actinomycete Bacteria Producing Antifungal Metabolites which could be used in Biological Control against a Phytopathogenic Fungus (Rhizopus Stolonifer). American Journal of Biology and Life Sciences. 2 (4), 84-89.

FAO. 2008 - FAOSTAT. Food and Agriculture Organization of the United Nations http://faostat.fao.org/default.aspx

FAO. 2014 - http://faostat3.fao.org/faostat-gateway/go/to/home/E [accessed 11.08.15]. 
FIED. 2018 - Peach, Nectarine Output Over $1 \mathrm{~m}$ Tons. Financial Tribune pp1 https://financialtribune.com/articles/economy-domestic-economy/74343/peach-nectarineoutput-over-1m-tons. 3/03/2018.

Horwitz W. 1975 - Official methods of analysis of the Association of Official Analytical Chemist (AOAC). Washington, USA.

Ingrao C, Matarazzo A, Tricase C, Clasadonte MT, Huisingh D. 2015 - Life cycle assessment for highlighting environmental hotspots in Sicilian peach production systems Journal of Clean Production 92,109-20.

Inouye S, Uchida K, Abe S. 2006 - Vapor activity of 72 essential oils against a Trichophyton mentagrophytes. Journal of Infection. Chemotherapy 12, 210-216.

Inouye S, Uchida K, Yamaguchi H. 2001 - In-vitro and in-vivo anti-Trichophyton activity of essential oils by vapour contact. Mycoses 44, 99-107.

ITA. 2016 - Iran Fruits and Vegetables Market 1, 1-8

Matan N, Rimkeeree H, Mawson AJ, Chompreeda P et al. 2006 - Antimicrobial activity of cinnamon and clove oils under modified atmosphere conditions. International Journal of Food Microbiology, 107(2), 180-185.

Mohammadi S, Aminifard MH. 2012 - Effect of Essential Oils on Postharvest Decay and Some Quality Factors of Peach (Prunus persica var. Redhaven) Journal of. Biology and. Environmental. Sceince 6(17), 147-153

Pina-Vaz C, Rodrigues AG, Pinto E. 2004 - Antifungal activity of Thymus oils and their major compounds. Journal of European. Academy of Dermatology and Venereology. 18, 73-78.

Rapisarda P, Fanella F, Maccarone E. 2000 - Reliability of analytical methods for determining anthocyanins in blood orange juices. Journal Agriculture Food Chemistry 48, 2249-2252.

Rattanapitigorn P, Arakawa M, Tsuro M. 2006 - Vanillin enhances the antifungal effect of plant essential oils against Botrytis cinerea. The International Journal of Aromatherapy 16, 193198

Serrano M, Martinez Romero D, Castillo S, Guillen F, Valero D. 2005 - The use of the natural antifungal compounds improves the beneficial effect of MAP in sweet cherry storage.Innovative Food Science and Emerging Technology 6, 115-121.

Soylu M, Kurt S, Soylu S. 2010 - In vitro and in vivo antifungal activities of the essential oils of various plants againsttomato grey mould disease agent Botrytis cinerea. International Journal of Food Microbiology 143, 183-189.

Takayuki S, Mami S, Azizi M, Yoshiharu F. 2007 - Antifungal effects of volatile compounds from black zira (Bunium persicum) and other spices and herbs. Journal Chemistry Ecology 33, 2123-2132.

Tomlinson S, Palombo EA. 2005 - Characterisation of antibacterial Australian medicinal Plant extracts by investigation of the mechanism of action and the effect of interfering substances. Journal of Basic Microbiology 45, 363-370.

Ultee A, Kets EPW, Smid EJ. 1999 - Mechanisms of action of carvacrol on the foodborne pathogen Bacillus cereus. Applied. Environmental Microbiology 65, 4606-4610.

Wang CY, Wang SY, Chien C. 2008 - Increasing antioxidant activity and reducing decay of blueberries by essential oils. Journal of Agriculture and Fruit Chemistry 56, 3587-3592.

Williamson B, Tudzynski B, Tudzynski P, Van Kan JAL. 2007 - Botrytis cinerea: the cause of grey mould disease. Molecular Plants Pathology 8, 561-580.

Wilson LC, Franklin JD, Otto B. 1987 - Fruits volatiles inhibitory to Monilinia fructicola and Botrytis cinerea. Journal Plant Disease 71, 316-319.

Yemm EW, Willis AJ. 1954 - The Estimation of Carbohydrate in the Plant Extract by Anthrone Reagent. Journal of Biochemistry 57, 508-514. 